Int. J. Electrochem. Sci., 11 (2016) $7020-7030$

\title{
Structural and Electrochemical Properties of Electrodeposited Ni-P nanocomposite Coatings Containing Mixed Ceramic Oxide Particles
}

\author{
K. M. Zadeh, R. A. Shakoor*, A. Bahgat Radwan \\ Center for Advanced Materials (CAM), Qatar University (QU), Doha 2713, Qatar \\ "E-mail: shakoor@qu.edu.qa
}

doi: $10.20964 / 2016.08 .42$

Received: 8 May 2016 / Accepted: 11 June 2016 / Published: 7 July 2016

\begin{abstract}
Mixed oxide ceramic particles were incorporated into Ni-P matrix to synthesize $\mathrm{Ni}-\mathrm{P}-\mathrm{TiO}_{2}-\mathrm{CeO}_{2}$ nanocomposite coatings. In the present study, the effect of concentration of mixed oxide ceramic particles $\left(\mathrm{TiO}_{2}\right.$ and $\left.\mathrm{CeO}_{2}\right)$ on structural, surface and electrochemical properties of Ni-P coating is investigated. The coatings were electrodeposited on mild steel substrate and were then characterized using various techniques. The compositional (EDAX) confirms the co-deposition of $\mathrm{TiO}_{2}$ and $\mathrm{CeO}_{2}$ ceramic particles into Ni-P matrix. The structural analysis (XRD) indicates that addition of mixed oxide ceramic particles do not have any prominent influence on the structure of Ni-P coatings as parent amorphous structure is preserved even at high concentration of mixed ceramic particles $(7.5 \mathrm{~g} / \mathrm{l})$. The SEM and AFM analyses indicate that the synthesized coatings are of fine nodular morphology containing uniformly distributed ceramic particles. However, their excessive amount may lead to agglomeration and surface defects. The surface analysis (AFM) also indicates that the surface roughness increases with the increase in amount of $\mathrm{TiO}_{2}$ and $\mathrm{CeO}_{2}$ particles. The enhancement in roughness of coatings can be ascribed to the fact the added ceramic particles are hard and remain insoluble in the Ni-P matrix. The potentiodynamic polarization analysis confirms that incorporation of mixed oxide ceramic particles into Ni-P matrix improves its anticorrosion properties. However, their excessive amount may cause decrease in corrosion resistance due to formation of galvanic cells at the defective metal/coating interface.
\end{abstract}

Keywords: Coatings, composite, crystal structure, hardness, roughness, corrosion

\section{$\underline{\text { FULLTEXT }}$}

(C) 2016 The Authors. Published by ESG (www.electrochemsci.org). This article is an open access article distributed under the terms and conditions of the Creative Commons Attribution license (http://creativecommons.org/licenses/by/4.0/). 